\title{
NURR1 Alterations in Perinatal Stress: A First Step towards Late-Onset Diseases? A Narrative Review
}

\author{
Laura Bordoni ${ }^{1}$, Irene Petracci ${ }^{2}$, Jean Calleja-Agius ${ }^{3}$, Joan G. Lalor ${ }^{4}$ and \\ Rosita Gabbianelli ${ }^{1, *(\mathbb{D})}$ \\ 1 Unit of Molecular Biology and Nutrigenomics, School of Pharmacy, University of Camerino, \\ 62032 Camerino, Italy; laura.bordoni@unicam.it \\ 2 School of Advanced Studies, University of Camerino, 62032 Camerino, Italy; irene.petracci@unicam.it \\ 3 Department of Anatomy, Faculty of Medicine and Surgery, University of Malta, MSD2080 Msida, Malta; \\ jean.calleja-agius@um.edu.mt \\ 4 School of Nursing and Midwifery, Trinity College Dublin, 24 D'Olier Street, Dublin 2, Ireland; j.lalor@tcd.ie \\ * Correspondence: rosita.gabbianelli@unicam.it; Tel.: +39-0737-634308
}

Received: 5 November 2020; Accepted: 7 December 2020; Published: 8 December 2020

\begin{abstract}
Perinatal life represents a delicate phase of development where stimuli of all sorts, coming to or from the mother, can influence the programming of the future baby's health. These stimuli may have consequences that persist throughout adulthood. Nuclear receptor related 1 protein (NURR1), a transcription factor with a critical role in the development of the dopaminergic neurons in the midbrain, mediates the response to stressful environmental stimuli in the perinatal period. During pregnancy, low-grade inflammation triggered by maternal obesity, hyperinsulinemia or vaginal infections alters NURR1 expression in human gestational tissues. A similar scenario is triggered by exposure to neurotoxic compounds, which are associated with NURR1 epigenetic deregulation in the offspring, with potential intergenerational effects. Since these alterations have been associated with an increased risk of developing late-onset diseases in children, NURR1, alone, or in combination with other molecular markers, has been proposed as a new prognostic tool and a potential therapeutic target for several pathological conditions. This narrative review describes perinatal stress associated with NURR1 gene deregulation, which is proposed here as a mediator of late-onset consequences of early life events.
\end{abstract}

Keywords: perinatal stress; NURR1; inflammation; late-onset diseases; early life

\section{Introduction}

Perinatal stress due to various environmental stimuli can have an impact on early fetal development, leading to long-term effects on cellular homeostasis [1-4]. Both prenatal and postnatal factors such as maternal nutrition, environmental pesticide exposure, stress, suboptimal antenatal care and neonatal trauma can cause epigenetic changes and impaired gene expression, especially at the neuronal level, with a consequent impact on fetal brain development and function [5].

According to the Barker hypothesis, in utero and postnatal stressors permanently program the structure and the physiology of the offspring, as a manifestation of the developmental plasticity to specific environmental stimuli [6]. This plasticity appears advantageous since it creates phenotypes that, once outside of the womb, are better matched to the environment that they are expected to enter into [6]. However, if in utero conditions do not match those following childbirth, this adaptive response could turn into a harmful mechanism. For instance, if the imprint left by a limited availability of nutrients during the prenatal stage is followed by overnutrition later in childhood, the risk of developing metabolic disorders increases, with consequent permanent changes in the metabolism of 
glucose-insulin established in the prenatal period [7]. The duration and timescale of exposure to various stimuli in early life are of key importance due to perinatal epigenetic plasticity. The interplay between environmental stimuli and genetic susceptibility in response to environmental stress is of a crucial importance in determining the final phenotype. Several genes play key roles in counterbalancing stress and maintaining cellular homeostasis. In the brain, the nuclear receptor related 1 protein (NURR1), a transcription factor able to modulate differentiation, survival and function of dopaminergic neurons, has been demonstrated to exert a neuroprotective role against neuropathological stress or insults. NURR1, as a glucocorticoid-responsive transcription factor, has an important endocrine regulatory role. It is a key factor in modulating the adaptive responses to stress by influencing the transcription of target genes in the hypothalamus-pituitary-adrenal axis (HPA), the major stress-responsive neuroendocrine system [8,9]. Changes in NURR1 expression have been observed in neurodegenerative conditions such as Parkinson's disease (PD) and Alzheimer's disease (AD), as well as in stroke and in multiple sclerosis $[10,11]$. NURR1 deregulation is also a causative factor for the onset of schizophrenia, through the modulation of genes associated with this pathology, particularly the dopamine D2 receptor co-expression gene set $[12,13]$. Considering epidemiological data on human cohorts [14-16] as well as the outcomes observed in PD animal models [17-21], it has been demonstrated that environmental stress during early life influences the programming of adult neuronal health. Thus, neonatal life represents the starting point during which the control of environmental stimuli can significantly drive the onset of neurodegeneration and other late-onset diseases.

This narrative review aims to describe the long-term effects of major environmental stressors occurring during the perinatal period and that affect NURR1 gene regulation. PubMed database was used for the search of peer-reviewed original research articles in English, published up to October 2020, without including electronic early-release publications. Search terms included "Nurr1" or "Nr4a2" and "disease" or "early-life" or "perinatal or prenatal" or "stress" or "trauma" or "inflammation" or "epigenetics" or "environmental exposure". The abstracts of retrieved citations were reviewed and prioritized by relevant content. Full articles were collected and secondary references from these articles were screened for inclusion.

This manuscript discusses how early determinants and maternal stress in perinatal life can modulate dopaminergic neuron homeostasis, as well as inflammatory and metabolic pathways, and affect health status later in life. The value of the early identification of risk factors lies in the fact that it may assist the introduction of prevention strategies aimed at reducing the burden of chronic diseases later in life. Consequently, it will assist policymakers to adopt appropriate clinical guidelines to prevent neuronal damage and inflammation-related diseases.

\section{Early Determinants of Human Health}

Increasing rates of prevalence of noncommunicable diseases (NCDs) (i.e., heart disease, diabetes, chronic respiratory diseases, cancer, $\mathrm{PD}, \mathrm{AD}$, mental illness, etc.) over recent decades, have been well-documented on a global scale. It is of particular concerning that the age of onset is reducing $[22,23]$. Major risk factors associated with the onset of NCDs are unhealthy diet, physical inactivity, alcohol consumption, smoking, air pollution and food xenobiotic exposure [24,25]. Considering the experimental, clinical and epidemiological evidence on the impact of early life on a wide range of NCDs, epigenetic processes occurring during the perinatal period have been identified as major mechanisms in the regulation of health later in life [26]. Human health can be programmed during prenatal and postnatal life as nutrition, life style, environment and genetics regulate gene expression and shape the phenotype. Starting from early prenatal life, parental exposure to healthy and unhealthy factors influence the child's epigenome, driving long-term effects on the adult health [27]. Paternal body weight, maternal caloric overload, junk food consumption and malnutrition exert their impact not only on child body weight at birth, but also on his/her inflammatory responses. A correlation between prenatal maternal depression and cytokine levels has been observed in postmortem fetal brains in response to the maternal condition, suggesting that proinflammatory cytokine genes can be expressed in specific fetal brain regions and may influence their development [28-30]. 
Furthermore, maternal education can influence the duration of breastfeeding, which impacts the infant's oral tolerance through immune modulation, the epithelial barrier function, the intestinal microbiome and body weight [31,32]. Shorter lengths of breastfeeding have been associated with increased proinflammatory responses, such as the production of interleukin 6 (IL-6) and C-reactive protein in the mother and in her offspring when reaching adulthood [33].

Social determinants of health, such as local neighborhood, social environment, exposure to chronic stress, education levels, socioeconomic status and access to health care, can cause epigenetic perturbations that influence disease susceptibility throughout life [34]. Social inequalities such as lower parental income/wealth, educational attainment, occupational social class, parental unemployment and lack of housing have been linked to unfavorable child health and development [35]. Poor housing conditions impact indoor air quality, leading, for example, to worsening asthma by epigenetic modulation [34]. Furthermore, in disadvantaged areas, the intake of healthy food is limited, with an excess of regular consumption of ultra-processed food, alcohol and tobacco, which contribute to the development of unhealthy phenotypes [34]. A low socioeconomical status, increased maternal weight and physical inactivity have been found to be related to children's weight and height [36,37]. A direct correlation between family income and child health also exists. In the United States of America, children aged $<17$ years living in poor families are at an increased risk of suffering from poor health [38]. All in all, the social determinants of health have been defined by the World Health Organization as "the conditions in which people are born, grow, live, work and age" and "the fundamental drivers of these conditions" can affect health-related behaviors. Levels of family income and education are strongly associated with a wide range of health outcomes. Life expectancy in men and women and infant mortality rate are directly related to educational attainment. Parental education has an impact on children's health because it influences dietary choices and exercise options early in life [38]. Finally, in addition to lifestyle-related determinants of health, traumatic events occurring in the perinatal life can also have a major impact on the child's future health.

\section{Stressful Events that Might Occur in Perinatal Life}

Several stressful events might occur during the perinatal life, thus impacting on the health status of children both in early and later life, in particular as they are related to the development of the central nervous system (CNS). Prenatal exposure to inflammatory insults has been shown to lead to neurodevelopmental disorders [39]. In particular, maternal infection has been associated with long-term neurological and neuro-psychiatric morbidity in the offspring [40]. Maternal immune activation in animal models induces transgenerational effects on the brain and behavior [41]. Maternal chorioamnionitis is associated with cerebral palsy in the offspring, independently of other factors such as preterm delivery and birthweight [42]. Prematurity is associated with perinatal neuroinflammation and injury [43], and maternal inflammation has been identified as a major risk factor for premature birth. After birth, premature infants often require supplemental oxygen for survival, and this exposure can lead to additional inflammatory responses. Adults born preterm are at an increased risk of suffering from long-term conditions as a consequence of the severe disruption of the normal developmental maturation of organ systems. These adverse health problems, which tend to appear earlier in the pre-term-born population, include neurological and mental health problems, hypertension, diabetes, cardiac dysfunction and obstructive lung disease [44]. Instead, the risk of developing asthma and allergic diseases in adult life is higher in babies born by caesarean section $[45,46]$. Babies born by caesarean section have a reduced diversity of gut microflora when compared to babies delivered vaginally, and this seems to be the most likely explanation for the increase in allergic diseases, given the impact of gastrointestinal flora on the neonate's immune system $[47,48]$. Maternal thyroid hormones are essential for normal neurodevelopment in the offspring, even after the onset of fetal thyroid function. This is particularly relevant for preterm infants who are deprived of maternal thyroid hormones following birth, who are at risk of suffering from hypothyroidism, and more likely to develop attention-deficit/hyperactivity disorder [49]. Rat models show that hypothyroid lactating females have a persistent low-quality milk, 
and both male and female hypothyroid offspring born of hypothyroid mothers gain less body mass with lower total adipose reserves and higher visceral reserves. The hypothyroid offspring also have higher levels of blood glucose, insulin and leptin, as well as dyslipidemia [50]. These long-term anthropometric effects have also been observed in humans [49]. Maternal diet has both short-term and long-term implications on fetal and child health. Maternal malnutrition can lead to micronutrient inadequacies and a suboptimal macronutrient balance [51-53]. For example, vitamin D deficiency together with maternal immune activation during development can induce schizophrenia-relevant dopaminergic abnormalities in the adult offspring of animal models [54]. Treating mothers with vitamin D could possibly lead to early neuroprotection to the fetus, since it has been shown to increase the number and the expression of mature Nurr1 mesencephalic dopaminergic neurons. Similar findings were observed in mothers with vitamin B deficiencies [55]. Bad eating habits can lead to maternal obesity with undesirable metabolism, which in turn influence the maternal health and, in the infant, lead to longer-term metabolic, neuropsychiatric and cognitive health consequences [56-58]. For instance, altered levels of plasma ceramides in the offspring of obese mothers have been implicated as early predictors of metabolic disease [59]. Maternal obesity has been implicated as being an independent risk factor of short- and long-term neuropsychiatric disorders in the offspring [60]. Low-grade inflammation is a central feature of pregnancies complicated by maternal obesity. This has also been observed in maternal type 2 diabetes, including gestational diabetes mellitus (GDM) [61]. Exposure in utero to maternal hyperglycemia, and consequent fetal hyperinsulinemia, carries not only several short-term consequences in the offspring, but also prompts metabolic imprinting that results in a greater risk of adverse long-term metabolic outcomes later in life. In particular, exposure in utero to maternal diabetes seems to influence long-term metabolic outcomes. The offspring of obese and/or mothers with diabetes carry a higher risk of obesity and type 2 diabetes, thus leading to a vicious cycle for future generations [62]. Exposure to toxins, including maternal smoking, is detrimental to the offspring. Animal models confirm that prenatal exposure to gestational nicotine before neurulation has a negative impact on the offspring's neurodevelopment [63]. Epidemiological studies show that in utero exposure to maternal active and passive smoking has long-term neurological effects on the children [64,65]. This has also been demonstrated for other environmental toxins, such as perchlorate [66]. Similarly, the safety of anesthetic agents has been questioned due to the occurrence of apoptotic neurodegeneration and permanent cognitive deficiencies in immature animals after exposure to anesthetic agents [67].

\section{NURR1: An Orphan Nuclear Receptor at the Interface between Neural Development, Inflammation and the Environment}

NURR1, also called NR4A2, is a nuclear receptor and a transcription factor that belongs to the NR4A subfamily of nuclear receptors, which also includes NOR-1 and NUR77. NURR1 shares structural similarities with the other NR4A family members. It consists of a modulator domain at the N-terminus, referred to as the activation function (AF)-1, a central double zinc finger DNA-binding domain (DBD), a ligand-binding domain (LBD) composed of $12 \alpha$-helices and its transactivation-dependent AF-2 at the C-terminus [68]. Similar to the other two members of this subfamily, NOR-1 and NUR77, NURR1 falls within the category of orphan receptors, since no specific ligand has yet been identified [69]. Because of the steric bulk of several hydrophobic residues, NURR1 (as well as other NR4A family members) does not have a LBD cavity, which explains the difficulty in finding proper ligands that can directly activate NURR1 through its LBD [70]. Instead, NURR1 transcriptional activity seems to rely on the AF-1 domain [71]. However, residues 592, 593, and 577 in the NURR1 LBD can be the site of interaction with some regulatory compounds [72,73]. For example, omega-3 docosahexaenoic acid has recently been shown to have high affinity for the NURR1 LBD, modulating NURR1 transactivation [74]. NURR1 exists as an active transcription factor in both its monomeric and homodimeric forms. As a monomer, NURR1 binds the nerve growth factor-inducible- $\beta$-binding response element (NBRE; $5^{\prime}$-AAAGGTCA-3'), while as a homodimer, it binds the nur-response element (NurRE; 5'-TGACCTTT-n6-AAAGGTCA-3'), resulting in the activation of several genes, including the tyrosine hydroxylase $(\mathrm{TH})$ and the dopamine 
active transporter (DAT) genes [75]. Indeed, NURR1 is widely expressed in the CNS where it has a crucial role in the differentiation of midbrain dopaminergic (DA) neurons. NURR1 is expressed during DA neuron differentiation in limbic areas and in the ventral midbrain where it regulates dopamine synthesis through proteins such as TH, DAT, vesicular monoamine transporter 2 (VMAT2) and RET receptor tyrosine kinase. Deficient expression of NURR1 in developing mesencephalic dopaminergic cells impairs them with regard to expressing TH [76,77]. NURR1 deficiency in embryonic ventral midbrain cells impairs their migration and their ability to innervate striatal target areas [78]. Given its well-established role in the CNS, altered functionality of NURR1 has been also associated with neurodegeneration (PD in particular), but also with attention-deficit/hyperactivity disorder [79], schizophrenia and manic-depressive disorders [80]. Moreover, a de novo deletion-induced haploinsufficiency of NR4A2 receptors is implicated in neurodevelopmental alterations, in particular language impairment [81]. The role of NURR1 at the interface with environmental stimuli in the management of stressful events has been demonstrated $[82,83]$. There is evidence that NURR1 transcription factor plays a prominent role in adaptive responses to stress, regulating the transcription of target genes in the HPA axis [71]. Moreover, NURR1 activity seems to be enhanced upon the interaction with the glucocorticoid receptor (GR) [84]. Rapid increase in NURR1 mRNA expression has been measured in limbic and cortical brain structures related to coping with depression-like behavior in mice [85,86], suggesting that an increase in NURR1 expression might be a compensatory mechanism to counteract the changes in forebrain dopamine transmission while coping with acute stress. The direct relationship of NURR1 with the environment is also suggested by its association with circadian rhythms and catecholamine production [87]. Prenatal stress modulates NURR1 inducing different outcomes along the life span of the male offspring, leading to changes in the reproductive system and spermatogenesis after puberty [8]. Beyond its well-known role in the development, function and maintenance of midbrain dopaminergic neurons [88], NURR1 can also be found in non-neuronal tissues such as synovial tissues, bone, endothelial cells, adrenal gland, hepatocytes and macrophages [83,89], where it mediates essential physiological processes, including adaptive and innate immune cell differentiation, metabolism and inflammation [90]. Thus, the nuclear receptor superfamily has been proposed as key transcription factors capable of modulating both immune and metabolic pathways. Since the discovery that NURR1 is not only involved in neurodegenerative disorders but also in inflammatory processes, growing attention has been directed to explore the potential role of NURR1 alterations in several inflammation-related diseases (including obesity and diabetes, atherosclerosis, cancer) [91-95]. In fact, the NURR1 receptor can be rapidly induced by a range of cytokines, suggesting that this receptor acts as a potential transcriptional mediator of inflammatory signals [83,96]. It has shown an anti-inflammatory function [97], but the exact molecular mechanisms have not been clearly elucidated yet. Recently, NURR1 has been shown to be responsive to nonsteroidal anti-inflammatory drugs [98]. The pleiotropic effects of NURR1 and its interaction with environmental factors have contributed to the proposal of this transcription factor as a mediator of late-onset consequences of early life events [83,99-101]. Next, we review the current knowledge on NURR1 alterations in early life, especially in association with the previously mentioned perinatal stressful events, and the potential implications in premature prevention of late-onset diseases.

\section{Perinatal Stress Modulates NURR1 Expression: From Early-Life Stress to Late-Onset Diseases}

Differential regulations of NURR1 expression have been demonstrated in association with several environmental exposures, especially in early life. In relation to metabolic health, it must be considered that in human fetal membranes and myometrium, as well as other cells and tissues, NURR1 expression is rapidly and transiently induced by a wide range of stimuli, including hormones, cellular stress and inflammatory signals. Among these, obesity and GDM are of particular concern during pregnancy as they trigger low-grade systemic inflammation [102,103]. High levels of activated macrophages in the intestinal stroma of the placenta and circulating proinflammatory cytokines, such as TNF- $\alpha$, IL-1 $\beta$ and IL-6, are observed in overweight women or women with GDM. In particular, TNF- $\alpha$ is considered a predictor of insulin resistance during pregnancy and has been correlated with fetal 
adiposity [104]. Interestingly, it was found that proinflammatory stimuli from IL-1 $\beta$ and TNF- $\alpha$ upregulate NURR1 expression (as well as NUR77) in the placenta of women with GDM compared to body mass index-matched normal glucose tolerant pregnant women, even though the exact mechanism has not been elucidated yet $[105,106]$.

Upregulated levels of cytokines are also observed in case of maternal depression [28]. Depressive disorders, anxiety and post-traumatic stress disorders are associated with significantly elevated levels of circulating proinflammatory cytokines, such as IL-6, TNF- $\alpha$ and IL-1RA [29,107-109]. This may be due to the activation of central and peripheral immune cells releasing cytokines, and to the activation of the stress response system of the HPA axis by proinflammatory cytokines [110]. The directionality of the related cytokine-depressive behavior is still under investigation. Inflammation, which is accompanied by cytokine signaling, may play a role in the pathophysiology of psychiatric disorders [111]. Nevertheless, changes in cytokines levels could also follow as a consequence of the psychiatric disorder, for example, being induced by treatments with psychopharmacological agents or by weight changes that accompany acute episodes of the disorder [112].

No association was found between pre-existing maternal obesity and placental NURR1 expression. However, a positive correlation was found previously in adipose tissue, suggesting a tissue-dependent modulation of obesity-induced NR4A receptor expression [113]. Moreover, Veum and co-workers measured a strong upregulation of the NR4As in extreme obesity and normalization after fat loss, showing an altered adipose tissue expression of the NR4As in obesity [92]. Therefore, these stress-responsive nuclear receptors may modulate pathogenic potential in humans, and early-life trauma might stimulate their deregulation. In addition, human gestational tissues express NR4A receptors, which regulate the processes of parturition at term through the modulation of cytokines and growth factors [114-116]. NURR1 (and NUR77) knockdown on primary human trophoblast cells resulted in decreased TNF- $\alpha$ induced IL- 6 and IL-8 expression and secretion, revealing a possible proinflammatory effect of NURR1 in human placenta [105]. Inflammation has a central role during labor and delivery, because cytokines stimulate uterine activation via the NF-kB pathway inducing the release of prostaglandins [117]. NURR1 (and NUR77) expression is upregulated in human fetal membranes and myometrium as a consequence of spontaneous labor at term, which can explain the expression of proinflammatory and prolabor genes associated with fetal membrane rupture and myometrial contractions [118]. However, a similar effect is driven by bacterial infections, which are responsible for most spontaneous preterm births (before 32 weeks gestational age) [119] due to the inflammatory response triggered by bacterial products in human gestational tissues. In fetal membranes, NURR1 expression was upregulated by bacterial lipopolysaccharide, fibroblast-stimulating lipopeptide and peptidoglycan muramyl dipeptide, whereas flagellin also increased NURR1 expression in the myometrium. The upstream mechanisms behind NURR1 upregulation are not clear yet; however, NF-kB activation seems to be involved [118]. By disrupting the normal developmental maturation of organ systems, preterm birth may result in long lasting adverse effects in adult age. Increased blood pressure, reduced insulin sensitivity, impaired vascular growth, chronic kidney disease (especially in the case of intrauterine growth restriction or neonatal acute kidney injury) and significant chronic airway obstruction are the most common adverse consequences connected to preterm birth that persist through adulthood [43]. Concerning CNS health, prenatal or early postnatal stress are considered risk factors for the development of psychiatric disorders, addiction and the ability to cope with stress. Prenatal stress strongly impacts fetal brain development in rats. Rats exposed to different types of stress during the last week of pregnancy give birth to offspring with anomalies in neuronal development and brain morphology which persist through adulthood $[120,121]$. The underlying mechanism has been thought to be most likely due to changes in D2-type dopamine (DA) neurotransmission induced by prenatal stress [122]. NURR1 expression in dopaminergic neurons starts at embryonic day 10.5 before the appearance of the dopaminergic marker enzyme, TH (at embryonic day 11.5) and continues during adulthood [123]. A homeostatic function has been attributed to NURR1 in the case of stress. Levels of NURR1 were found to be increased in the ventral tegmental area of prenatally stressed adult offspring, most likely as a compensatory mechanism 
to counteract the reduction in dopamine levels observed as a consequence of prenatal stress [8,124]. A similar NURR1 increase was observed in cortical brain regions and the limbic system, including cornu ammonis-3 (CA3) of the hippocampus in mice, as a compensatory response to acute stress [85]. Montes et al. has shown that even if the hippocampus may be vulnerable to stress, it may also have enough plasticity to cope with stress. To test the resilience to stress of the hippocampus, NURR1 was downregulated in prenatally stressed (PS) and nonprenatally stressed (NPS) male rats, through the bilateral administration of NURR1 anti-sense oligodeoxynucleotide (ODN) into their hippocampal CA3 region. Then rats were exposed to an acute stressor (forced swimming test, FST) to analyze their behavioral responses. After the ODN treatment, NPS rats showed a depressive-like behavior manifested through immobility, while PS rats showed active behaviors (resilience). These findings suggest that prenatal stress might induce brain modifications that promote resilience to acute stress in adulthood [125]. Given the central role of NURR1 in the development of dopaminergic neurons, prenatal exposure to neurotoxic compounds, such as pesticides, could be implicated in its deregulation leading to the onset, later in life, of neurological disorders, such as PD. Exposure to atrazine (ATR), a volatile and water-soluble compound used as a herbicide worldwide, during pregnancy and lactation has been associated with decreased expression of NURR1 in offspring, together with changes in the expression of VMAT2, which controls the transport and reuptake of DA. The consequent decrease in DA levels in the striatum confirm that early-life exposure to ATR alters the dopaminergic system by modulating NURR1 expression [126]. Additionally, early-life exposure to permethrin (PERM), a pyrethroid compound largely used for outdoor/indoor pest control and as anti-woodworm agent, induces dopaminergic neuronal disorders in adult life, through the alteration of Nurr1 expression levels $[100,101,127]$. Of note, early-life exposure to PERM seems to have intergenerational effects, most likely due to epigenetic mechanisms [128]. An increased DNA methylation at the promoter region of the dopamine-specifying factor, Nurr1, has been observed in the sperm of first-generation offspring of these mothers. In the ventral midbrain of second-generation offspring, the effect is further associated with reduced mRNA levels of Nurr1 [41]. The effects in the later life of early NURR1 perturbation are endorsed by a body of evidence. Remarkably, it has been demonstrated that maternal smoking and early postnatal exposure to nicotine alter children's behaviors and increase their propensity for drug abuse later in life, by altering the dopamine-mediated reward system [129]. This most likely occurs due to the nicotine-mediated circuit activation during development. In fact, studies on mice show that neonatal exposure to nicotine primes midbrain neurons to express NURR1; subsequent nicotine re-exposures in adulthood induce primed neurons to acquire the dopaminergic phenotype responsible for nicotine-mediated neurotransmitter plasticity [129]. In addition, prenatal exposure to infections is a known risk factor for the development of neuropsychiatric disorders, especially schizophrenia and autism [130,131]. However, it seems that other risk factors, in particular genetic factors, should be concomitant to developing severe neuronal disorders. Brain and behavioral consequences of prenatal infection-induced immune activation are exacerbated (synergistic effects) in offspring with genetic predisposition to dopaminergic abnormalities, in particular NURR1 deficiency [132]. NURR1 polymorphisms may also be implicated in the etiology of disorders characterized by altered dopaminergic signaling, such as attention-deficit/hyperactivity disorder, schizophrenia and PD. Thus, NURR1 may represent a future candidate gene to study the genetic predispositions to several neuropsychiatric disorders [79,130]. Furthermore, preclinical studies on rodents and nonhuman primates have questioned the safety of anesthetic agents used to relieve pain in the process of childbirth or surgical procedures. It emerged that under common clinical conditions, these chemical agents have a neurotoxic effect on the developing brain and can also induce long-term neurobehavioral abnormalities [133]. In particular, the use of sevoflurane in pregnant women seems to strongly impact fetal brain development. Sevoflurane impairs hippocampal CNS proliferation and differentiation through the upregulation of miR-183 and the downregulation of NURR1. The result is the progressive degeneration of the fetal brain, with long-term deficits in hippocampal-dependent learning and memory [133]. Finally, several studies also support the hypothesis of the intermediary role of inflammation and perinatal trauma underpinning the link between early-life exposure, NURR1 
alterations, and CNS impairment later in life. Indeed, NURR1 expression may play a significant role in the modulation of brain development, especially in the case of a combination of maternal inflammation and premature birth. Premature infants often rely on supplemental oxygen for survival, which may represent an additional source of inflammation leading to neurodevelopmental impairment. Lallier et al. [134] found decreased numbers of oligodendrocytes and increased numbers of microglia in mice exposed to both maternal inflammation and neonatal hyperoxia. They hypothesized that alteration of NURR1 expression in the perinatal period could be responsible for the detrimental effects of the two combined sources of inflammation, bacterial infections and hypoxia [134]. Table 1 summarizes the main targets and modulators of NURR1.

Table 1. Main targets and modulators of Nuclear receptor related 1 protein (NURR1).

\begin{tabular}{cc}
\hline NURR1 Targets (T) and Modulators (M) & References \\
\hline Hypothalamus-pituitary-adrenal axis (T) & {$[8,9,71]$} \\
\hline $\begin{array}{c}\text { Dopamine D2 receptor, tyrosine hydroxylase, } \\
\text { dopamine active transporter, glucocorticoid receptor (T) }\end{array}$ & {$[12,13,75-77,84,85,122-126]$} \\
\hline Environmental stress during early life (M) & {$[8,14-21,82,83,99-101,129-134]$} \\
\hline Circadian rhythm and catecholamine production (T) & {$[87]$} \\
\hline Micronutrient intake (M) & {$[55-58]$} \\
\hline Omega-3 docosahexaenoic acid (M) & {$[74]$} \\
\hline $\begin{array}{c}\text { Adaptive and innate immune cell differentiation, } \\
\text { metabolism and inflammation in various cells (T) }\end{array}$ & {$[83,90-98,105,135]$} \\
\hline IL-1 $\beta$ and TNF- $\alpha(\mathrm{M})$ & {$[29,104-110]$} \\
\hline Obesity $(\mathrm{M})$ & {$[92,113]$} \\
\hline Human gestational tissues (T) & {$[114-116,118]$} \\
\hline Permethrin $(\mathrm{M})$ & {$[41,100,101,127,128]$} \\
\hline
\end{tabular}

\section{NURR1: An Early Biomarker and Novel Target for Prevention of Chronic Diseases?}

Given the expression of NURR1 not only in the CNS but also in other tissues, such as adipose tissue, liver, skeletal muscles and heart tissues, a perturbation of its functionality can have a broad spectrum of consequences for human health, from neurological and psychiatric disorders to metabolic diseases. NURR1 is mainly known for its primary role in the development of dopaminergic neurons; however, it has been shown to be a significant dual actor in the inflammation process. While there is evidence of the anti-inflammatory behavior of NURR1 [135], other findings have associated NURR1 expression levels with increased proinflammatory cytokines, in particular in pathologies such as PD and type 2 diabetes, suggesting a potential of NURR1 in the etiology of these conditions [11,93]. Even though further research to clarify the mechanistic effects of NURR1 is needed, the usage of NURR1 expression as a biomarker has been proposed, at least for those conditions in which NURR1 deregulation has been established. The assessment of NURR1 levels in blood gave good results in aiding in the diagnosis of PD and monitoring disease progression when measured in association with mir-132 or cytokines [136,137]. Other findings also suggest NURR1 as a biomarker for early diagnosis or diseases' progression [93,138]. Additional studies investigating the role of NURR1 in predicting long-term effects of perinatal stress are warranted in order to extend the usage of NURR1 as a biomarker for other relevant clinical conditions.

In addition, NURR1 has been suggested as a potential pharmacological target for diseases characterized by its deregulation $[139,140]$. As an example, it has been demonstrated that the GR can act as a transcriptional regulator of NURR1, suggesting that glucocorticoids might be used to regulate NURR1 expression [87]. At present, a significant number of research projects aimed at identifying new NURR1 ligands for drug development are underway [141-143]. 
Moreover, knowledge that NURR1 expression can be regulated by modifiable factors (i.e., nutritional status) might pave the way for potential applications of nutrigenomics [144] in the early prevention of the previously mentioned conditions through strategies aimed to improve nutrition in the perinatal period and in early childhood.

\section{Conclusions}

The interactions between NURR1 and environmental factors, especially during early fetal development, are well-documented and are implicated in a variety of late-onset consequences for human health [99]. When considering that an intergenerational transmission of NURR1-mediated effects has been hypothesized [41,128], the ability of external stressors to control of NURR1 expression gains even more importance. This is of particular significance in the context of the prenatal and early neonatal periods. Further investigations to explore the role of NURR1 either alone or in combination with other molecular markers as a noninvasive biomarker, aiding in the prevention, diagnosis and evaluation of disease severity or response to treatments for several pathological conditions, should be considered.

Author Contributions: Conceptualization, R.G., L.B., J.C.-A.; writing-original draft preparation, L.B., R.G., I.P., J.C.-A.; writing—review and editing, R.G., L.B., J.C.-A. and J.G.L.; funding acquisition, J.G.L. All authors have read and agreed to the published version of the manuscript.

Funding: The publication of this manuscript was funded by COST Action CA18211:DEVoTION:Perinatal Mental Health and Birth-Related Trauma: Maximizing best practice and optimal outcomes (European Cooperation in Science and Technology).

Acknowledgments: This publication emerged from the EU funded COST action CA18211:DEVoTION: Perinatal Mental Health and Birth-Related Trauma: Maximizing best practice and optimal outcomes. R.G., J.C.A. and J.G.L. are authors, R.G., J.C.A. are Action management committee members and J.G.L. is the Action Chair.

Conflicts of Interest: The authors declare no conflict of interest.

\section{References}

1. Lähdepuro, A.; Savolainen, K.; Lahti-Pulkkinen, M.; Eriksson, J.G.; Lahti, J.; Tuovinen, S.; Kajantie, E.; Pesonen, A.-K.; Heinonen, K.; Räikkönen, K. The Impact of Early Life Stress on Anxiety Symptoms in Late Adulthood. Sci. Rep. 2019, 9, 4395. [CrossRef] [PubMed]

2. Hori, H.; Kim, Y. Inflammation and post-traumatic stress disorder. Psychiatry Clin. Neurosci. 2019, 73, $143-153$. [CrossRef] [PubMed]

3. Merrill, D.A.; Masliah, E.; Roberts, J.A.; McKay, H.; Kordower, J.H.; Mufson, E.J.; Tuszynski, M.H. Association of early experience with neurodegeneration in aged primates. Neurobiol. Aging 2011, 32, 151-156. [CrossRef] [PubMed]

4. Carroll, J.C.; Iba, M.; Bangasser, D.A.; Valentino, R.J.; James, M.J.; Brunden, K.R.; Lee, V.M.-Y.; Trojanowski, J.Q. Chronic stress exacerbates tau pathology, neurodegeneration, and cognitive performance through a corticotropin-releasing factor receptor-dependent mechanism in a transgenic mouse model of tauopathy. J. Neurosci. 2011, 31, 14436-14449. [CrossRef]

5. Gabbianelli, R.; Damiani, E. Epigenetics and neurodegeneration: Role of early-life nutrition. J. Nutr. Biochem. 2018, 57, 1-13. [CrossRef]

6. Barker, D.J.P. The origins of the developmental origins theory. J. Intern. Med. 2007, 261, 412-417. [CrossRef]

7. Hales, C.N.; Barker, D.J.P. The thrifty phenotype hypothesis: Type 2 diabetes. Br. Med. Bull. 2001, 60, 5-20. [CrossRef]

8. Pallarés, M.E.; Antonelli, M.C. Hormonal modulation of catecholaminergic neurotransmission in a prenatal stress model. Adv. Neurobiol. 2015, 10, 45-59.

9. Murphy, E.P.; Conneely, O.M. Neuroendocrine regulation of the hypothalamic pituitary adrenal axis by the nurr1/nur77 subfamily of nuclear receptors. Mol. Endocrinol. 1997, 11, 39-47. [CrossRef]

10. Jeon, S.G.; Yoo, A.; Chun, D.W.; Hong, S.B.; Chung, H.; Kim, J.-I.; Moon, M. The Critical Role of Nurr1 as a Mediator and Therapeutic Target in Alzheimer's Disease-related Pathogenesis. Aging Dis. 2020, 11, 705-724. [CrossRef] 
11. Li, T.; Yang, Z.; Li, S.; Cheng, C.; Shen, B.; Le, W. Alterations of NURR1 and Cytokines in the Peripheral Blood Mononuclear Cells: Combined Biomarkers for Parkinson's Disease. Front. Aging Neurosci. 2018, 10, 392. [CrossRef] [PubMed]

12. Torretta, S.; Rampino, A.; Basso, M.; Pergola, G.; Di Carlo, P.; Shin, J.H.; Kleinman, J.E.; Hyde, T.M.; Weinberger, D.R.; Masellis, R.; et al. NURR1 and ERR1 Modulate the Expression of Genes of a DRD2 Coexpression Network Enriched for Schizophrenia Risk. J. Neurosci. 2020, 40, 932-941. [CrossRef] [PubMed]

13. Corley, S.M.; Tsai, S.-Y.; Wilkins, M.R.; Shannon Weickert, C. Transcriptomic Analysis Shows Decreased Cortical Expression of NR4A1, NR4A2 and RXRB in Schizophrenia and Provides Evidence for Nuclear Receptor Dysregulation. PLoS ONE 2016, 11, e0166944. [CrossRef] [PubMed]

14. Holmes, L.J.; Shutman, E.; Chinaka, C.; Deepika, K.; Pelaez, L.; Dabney, K.W. Aberrant Epigenomic Modulation of Glucocorticoid Receptor Gene (NR3C1) in Early Life Stress and Major Depressive Disorder Correlation: Systematic Review and Quantitative Evidence Synthesis. Int. J. Environ. Res. Public Health 2019, 16, 4280. [CrossRef]

15. Luby, J.L.; Baram, T.Z.; Rogers, C.E.; Barch, D.M. Neurodevelopmental Optimization after Early-Life Adversity: Cross-Species Studies to Elucidate Sensitive Periods and Brain Mechanisms to Inform Early Intervention. Trends Neurosci. 2020, 43, 744-751. [CrossRef] [PubMed]

16. Hambrick, E.P.; Brawner, T.W.; Perry, B.D.; Brandt, K.; Hofmeister, C.; Collins, J.O. Beyond the ACE score: Examining relationships between timing of developmental adversity, relational health and developmental outcomes in children. Arch. Psychiatr. Nurs. 2019, 33, 238-247. [CrossRef]

17. Nasuti, C.; Brunori, G.; Eusepi, P.; Marinelli, L.; Ciccocioppo, R.; Gabbianelli, R. Early life exposure to permethrin: A progressive animal model of Parkinson's disease. J. Pharmacol. Toxicol. Methods 2017, 83, 80-86. [CrossRef]

18. Bordoni, L.; Nasuti, C.; Fedeli, D.; Galeazzi, R.; Laudadio, E.; Massaccesi, L.; López-Rodas, G.; Gabbianelli, R. Early impairment of epigenetic pattern in neurodegeneration: Additional mechanisms behind pyrethroid toxicity. Exp. Gerontol. 2019, 124, 110629. [CrossRef]

19. Nasuti, C.; Fattoretti, P.; Carloni, M.; Fedeli, D.; Ubaldi, M.; Ciccocioppo, R.; Gabbianelli, R. Neonatal exposure to permethrin pesticide causes lifelong fear and spatial learning deficits and alters hippocampal morphology of synapses. J. Neurodev. Disord. 2014, 6, 7. [CrossRef]

20. Bordoni, L.; Nasuti, C.; Di Stefano, A.; Marinelli, L.; Gabbianelli, R. Epigenetic Memory of Early-Life Parental Perturbation: Dopamine Decrease and DNA Methylation Changes in Offspring. Oxid. Med. Cell. Longev. 2019, 2019, 1472623. [CrossRef]

21. Bordoni, L.; Gabbianelli, R.; Fedeli, D.; Fiorini, D.; Bergheim, I.; Jin, C.J.; Marinelli, L.; Di Stefano, A.; Nasuti, C. Positive effect of an electrolyzed reduced water on gut permeability, fecal microbiota and liver in an animal model of Parkinson's disease. PLoS ONE 2019, 14, e0223238. [CrossRef]

22. Allen, L. Are we facing a noncommunicable disease pandemic? J. Epidemiol. Glob. Health 2017, 7, 5-9. [CrossRef]

23. Choo, C.C.; Chew, P.K.H.; Ho, R.C. Controlling Noncommunicable Diseases in Transitional Economies: Mental Illness in Suicide Attempters in Singapore-An Exploratory Analysis. Biomed Res. Int. 2019, 2019, 4652846. [CrossRef] [PubMed]

24. Reddy, K.S. Measuring mortality from non-communicable diseases: Broadening the band. Lancet Glob. Health 2020, 8, e456-e457. [CrossRef]

25. Bordoni, L.; Gabbianelli, R. Chapter 67-Nutrigenomics of Food Pesticides. In Principles of Nutrigenetics and Nutrigenomics; Caterina, R.D.E., Martinez, J.A., Kohlmeier, M., Eds.; Academic Press: Salt Lake City, UT, USA, 2020; pp. 513-518. ISBN 978-0-12-804572-5.

26. Hanson, M.A.; Gluckman, P.D. Developmental origins of health and disease-Global public health implications. Best Pract. Res. Clin. Obstet. Gynaecol. 2015, 29, 24-31. [CrossRef] [PubMed]

27. Gabbianelli, R. Modulation of the Epigenome by Nutrition and Xenobiotics during Early Life and across the Life Span: The Key Role of Lifestyle. Lifestyle Genom. 2018, 11, 9-12. [CrossRef] [PubMed]

28. Wu, Y.; Zhang, H.; Wang, C.; Broekman, B.F.P.; Chong, Y.-S.; Shek, L.P.; Gluckman, P.D.; Meaney, M.J.; Fortier, M.V.; Qiu, A. Inflammatory modulation of the associations between prenatal maternal depression and neonatal brain. Neuropsychopharmacology 2020. [CrossRef] [PubMed]

29. McQuaid, R.J.; Gabrys, R.L.; McInnis, O.A.; Anisman, H.; Matheson, K. Understanding the Relation Between Early-Life Adversity and Depression Symptoms: The Moderating Role of Sex and an Interleukin-1 $\beta$ Gene Variant. Front. Psychiatry 2019, 10, 151. [CrossRef] 
30. Dowlati, Y.; Herrmann, N.; Swardfager, W.; Liu, H.; Sham, L.; Reim, E.K.; Lanctôt, K.L. A meta-analysis of cytokines in major depression. Biol. Psychiatry 2010, 67, 446-457. [CrossRef]

31. Sarki, M.; Parlesak, A.; Robertson, A. Comparison of national cross-sectional breast-feeding surveys by maternal education in Europe (2006-2016). Public Health Nutr. 2019, 22, 848-861. [CrossRef]

32. Ortega-García, J.A.; Kloosterman, N.; Alvarez, L.; Tobarra-Sánchez, E.; Cárceles-Álvarez, A.; Pastor-Valero, R.; López-Hernández, F.A.; Sánchez-Solis, M.; Claudio, L. Full Breastfeeding and Obesity in Children: A Prospective Study from Birth to 6 Years. Child. Obes. 2018, 14, 327-337. [CrossRef] [PubMed]

33. Gabbianelli, R.; Bordoni, L.; Morano, S.; Calleja-Agius, J.; Lalor, J.G. Nutri-Epigenetics and Gut Microbiota: How Birth Care, Bonding and Breastfeeding Can Influence and Be Influenced? Int. J. Mol. Sci. 2020, $21,5032$. [CrossRef] [PubMed]

34. Mancilla, V.J.; Peeri, N.C.; Silzer, T.; Basha, R.; Felini, M.; Jones, H.P.; Phillips, N.; Tao, M.-H.; Thyagarajan, S.; Vishwanatha, J.K. Understanding the Interplay Between Health Disparities and Epigenomics. Front. Genet. 2020, 11, 903. [CrossRef] [PubMed]

35. Pillas, D.; Marmot, M.; Naicker, K.; Goldblatt, P.; Morrison, J.; Pikhart, H. Social inequalities in early childhood health and development: A European-wide systematic review. Pediatr. Res. 2014, 76, 418-424. [CrossRef]

36. Bann, D.; Johnson, W.; Li, L.; Kuh, D.; Hardy, R. Socioeconomic inequalities in childhood and adolescent body-mass index, weight, and height from 1953 to 2015: An analysis of four longitudinal, observational, British birth cohort studies. Lancet Public Health 2018, 3, e194-e203. [CrossRef]

37. Bann, D.; Fitzsimons, E.; Johnson, W. Determinants of the population health distribution: An illustration examining body mass index. Int. J. Epidemiol. 2020, 49, 731-737. [CrossRef]

38. Braveman, P.; Gottlieb, L. The social determinants of health: It's time to consider the causes of the causes. Public Health Rep. 2014, 129 (Suppl. 2), 19-31. [CrossRef]

39. Nazzari, S.; Frigerio, A. The programming role of maternal antenatal inflammation on infants' early neurodevelopment: A review of human studies: Special Section on "Translational and Neuroscience Studies in Affective Disorders" Section Editor, Maria Nobile MD, PhD. J. Affect. Disord. 2020, 263, 739-746. [CrossRef]

40. Al-Haddad, B.J.S.; Jacobsson, B.; Chabra, S.; Modzelewska, D.; Olson, E.M.; Bernier, R.; Enquobahrie, D.A.; Hagberg, H.; Östling, S.; Rajagopal, L.; et al. Long-term Risk of Neuropsychiatric Disease After Exposure to Infection In Utero. JAMA Psychiatry 2019, 76, 594-602. [CrossRef]

41. Weber-Stadlbauer, U.; Richetto, J.; Zwamborn, R.A.J.; Slieker, R.C.; Meyer, U. Transgenerational modification of dopaminergic dysfunctions induced by maternal immune activation. Neuropsychopharmacology 2020. [CrossRef]

42. Freud, A.; Wainstock, T.; Sheiner, E.; Beloosesky, R.; Fischer, L.; Landau, D.; Walfisch, A. Maternal chorioamnionitis \& long-term neurological morbidity in the offspring. Eur. J. Paediatr. Neurol. 2019, 23, 484-490. [PubMed]

43. Luu, T.M.; Rehman Mian, M.O.; Nuyt, A.M. Long-Term Impact of Preterm Birth: Neurodevelopmental and Physical Health Outcomes. Clin. Perinatol. 2017, 44, 305-314. [CrossRef] [PubMed]

44. Raju, T.N.K.; Buist, A.S.; Blaisdell, C.J.; Moxey-Mims, M.; Saigal, S. Adults born preterm: A review of general health and system-specific outcomes. Acta Paediatr. 2017, 106, 1409-1437. [CrossRef]

45. Xu, B.; Pekkanen, J.; Hartikainen, A.L.; Järvelin, M.R. Caesarean section and risk of asthma and allergy in adulthood. J. Allergy Clin. Immunol. 2001, 107, 732-733. [CrossRef] [PubMed]

46. Thavagnanam, S.; Fleming, J.; Bromley, A.; Shields, M.D.; Cardwell, C.R. A meta-analysis of the association between Caesarean section and childhood asthma. Clin. Exp. Allergy 2008, 38, 629-633. [CrossRef] [PubMed]

47. Biasucci, G.; Rubini, M.; Riboni, S.; Morelli, L.; Bessi, E.; Retetangos, C. Mode of delivery affects the bacterial community in the newborn gut. Early Hum. Dev. 2010, 86 (Suppl. 1), 13-15. [CrossRef]

48. Siggers, R.H.; Siggers, J.; Thymann, T.; Boye, M.; Sangild, P.T. Nutritional modulation of the gut microbiota and immune system in preterm neonates susceptible to necrotizing enterocolitis. J. Nutr. Biochem. 2011, 22, 511-521. [CrossRef]

49. Tapia-Martínez, J.; Torres-Manzo, A.P.; Franco-Colín, M.; Pineda-Reynoso, M.; Cano-Europa, E. Maternal Thyroid Hormone Deficiency During Gestation and Lactation Alters Metabolic and Thyroid Programming of the Offspring in the Adult Stage. Horm. Metab. Res. 2019, 51, 381-388. [CrossRef]

50. Muller, I.; Taylor, P.N.; Daniel, R.M.; Hales, C.; Scholz, A.; Candler, T.; Pettit, R.J.; Evans, W.D.; Shillabeer, D.; Draman, M.S.; et al. CATS II Long-term Anthropometric and Metabolic Effects of Maternal Sub-optimal Thyroid Function in Offspring and Mothers. J. Clin. Endocrinol. Metab. 2020, 105. [CrossRef] 
51. Rees, W.D. Interactions between nutrients in the maternal diet and the implications for the long-term health of the offspring. Proc. Nutr. Soc. 2019, 78, 88-96. [CrossRef]

52. Srugo, S.A.; Bloise, E.; Nguyen, T.T.-T.N.; Connor, K.L. Impact of Maternal Malnutrition on Gut Barrier Defense: Implications for Pregnancy Health and Fetal Development. Nutrients 2019, 11, 1375. [CrossRef] [PubMed]

53. Chong, M.F.-F.; Godfrey, K.M.; Gluckman, P.; Tan, K.H.; Shek, L.P.-C.; Meaney, M.; Chan, J.K.Y.; Yap, F.; Lee, Y.S.; Chong, Y.-S. Influences of the perinatal diet on maternal and child health: Insights from the GUSTO study. Proc. Nutr. Soc. 2020, 1-6. [CrossRef] [PubMed]

54. Luan, W.; Hammond, L.A.; Vuillermot, S.; Meyer, U.; Eyles, D.W. Maternal Vitamin D Prevents Abnormal Dopaminergic Development and Function in a Mouse Model of Prenatal Immune Activation. Sci. Rep. 2018, 8, 9741. [CrossRef]

55. Lai, J.S.; Mohamad Ayob, M.N.; Cai, S.; Quah, P.L.; Gluckman, P.D.; Shek, L.P.; Yap, F.; Tan, K.H.; Chong, Y.S.; Godfrey, K.M.; et al. Maternal plasma vitamin B12 concentrations during pregnancy and infant cognitive outcomes at 2 years of age. Br. J. Nutr. 2019, 121, 1303-1312. [CrossRef] [PubMed]

56. Godfrey, K.M.; Reynolds, R.M.; Prescott, S.L.; Nyirenda, M.; Jaddoe, V.W.V.; Eriksson, J.G.; Broekman, B.F.P. Influence of maternal obesity on the long-term health of offspring. Lancet Diabetes Endocrinol. 2017, 5, 53-64. [CrossRef]

57. Gaillard, R. Maternal obesity during pregnancy and cardiovascular development and disease in the offspring. Eur. J. Epidemiol. 2015, 30, 1141-1152. [CrossRef]

58. Gutvirtz, G.; Wainstock, T.; Landau, D.; Sheiner, E. Maternal Obesity and Offspring Long-Term Infectious Morbidity. J. Clin. Med. 2019, 8, 1466. [CrossRef]

59. León-Aguilar, L.F.; Croyal, M.; Ferchaud-Roucher, V.; Huang, F.; Marchat, L.A.; Barraza-Villarreal, A.; Romieu, I.; Ramakrishnan, U.; Krempf, M.; Ouguerram, K.; et al. Maternal obesity leads to long-term altered levels of plasma ceramides in the offspring as revealed by a longitudinal lipidomic study in children. Int. J. Obes. (Lond.) 2019, 43, 1231-1243. [CrossRef]

60. Neuhaus, Z.F.; Gutvirtz, G.; Pariente, G.; Wainstock, T.; Landau, D.; Sheiner, E. Maternal obesity and long-term neuropsychiatric morbidity of the offspring. Arch. Gynecol. Obstet. 2020, 301, 143-149. [CrossRef]

61. Farahvar, S.; Walfisch, A.; Sheiner, E. Gestational diabetes risk factors and long-term consequences for both mother and offspring: A literature review. Expert Rev. Endocrinol. Metab. 2019, 14, 63-74. [CrossRef]

62. Burlina, S.; Dalfrà, M.G.; Lapolla, A. Short- and long-term consequences for offspring exposed to maternal diabetes: A review. J. Matern. Neonatal Med. 2019, 32, 687-694. [CrossRef] [PubMed]

63. Omotoso, G.O.; Kadir, R.E.; Sulaimon, F.A.; Jaji-Sulaimon, R.; Gbadamosi, I.T. Prenatal Exposure to Gestational Nicotine before Neurulation is Detrimental to Neurodevelopment of Wistar Rats' Offspring. Malays. J. Med. Sci. 2018, 25, 35-47. [CrossRef] [PubMed]

64. Moore, B.F.; Starling, A.P.; Magzamen, S.; Harrod, C.S.; Allshouse, W.B.; Adgate, J.L.; Ringham, B.M.; Glueck, D.H.; Dabelea, D. Fetal exposure to maternal active and secondhand smoking with offspring early-life growth in the Healthy Start study. Int. J. Obes. (Lond.) 2019, 43, 652-662. [CrossRef] [PubMed]

65. Gutvirtz, G.; Wainstock, T.; Landau, D.; Sheiner, E. Maternal smoking during pregnancy and long-term neurological morbidity of the offspring. Addict. Behav. 2019, 88, 86-91. [CrossRef] [PubMed]

66. Rubin, R.; Pearl, M.; Kharrazi, M.; Blount, B.C.; Miller, M.D.; Pearce, E.N.; Valentin-Blasini, L.; DeLorenze, G.; Liaw, J.; Hoofnagle, A.N.; et al. Maternal perchlorate exposure in pregnancy and altered birth outcomes. Environ. Res. 2017, 158, 72-81. [CrossRef] [PubMed]

67. Jiang, J.; Li, S.; Wang, Y.; Xiao, X.; Jin, Y.; Wang, Y.; Yang, Z.; Yan, S.; Li, Y. Potential neurotoxicity of prenatal exposure to sevoflurane on offspring: Metabolomics investigation on neurodevelopment and underlying mechanism. Int. J. Dev. Neurosci. 2017, 62, 46-53. [CrossRef] [PubMed]

68. Ichinose, H.; Ohye, T.; Suzuki, T.; Sumi-Ichinose, C.; Nomura, T.; Hagino, Y.; Nagatsu, T. Molecular cloning of the human Nurr1 gene: Characterization of the human gene and cDNAs. Gene 1999, 230, 233-239. [CrossRef]

69. Germain, P.; Staels, B.; Dacquet, C.; Spedding, M.; Laudet, V. Overview of nomenclature of nuclear receptors. Pharmacol. Rev. 2006, 58, 685-704. [CrossRef]

70. Wang, Z.; Benoit, G.; Liu, J.; Prasad, S.; Aarnisalo, P.; Liu, X.; Xu, H.; Walker, N.P.C.; Perlmann, T. Structure and function of Nurr1 identifies a class of ligand-independent nuclear receptors. Nature 2003, 423, 555-560. [CrossRef] 
71. Maira, M.; Martens, C.; Batsché, E.; Gauthier, Y.; Drouin, J. Dimer-specific potentiation of NGFI-B (Nur77) transcriptional activity by the protein kinase A pathway and AF-1-dependent coactivator recruitment. Mol. Cell. Biol. 2003, 23, 763-776. [CrossRef]

72. Volakakis, N.; Malewicz, M.; Kadkhodai, B.; Perlmann, T.; Benoit, G. Characterization of the Nurr1 ligand-binding domain co-activator interaction surface. J. Mol. Endocrinol. 2006, 37, 317-326. [CrossRef] [PubMed]

73. Codina, A.; Benoit, G.; Gooch, J.T.; Neuhaus, D.; Perlmann, T.; Schwabe, J.W.R. Identification of a novel co-regulator interaction surface on the ligand binding domain of Nurr1 using NMR footprinting. J. Biol. Chem. 2004, 279, 53338-53345. [CrossRef] [PubMed]

74. de Vera, I.M.S.; Giri, P.K.; Munoz-Tello, P.; Brust, R.; Fuhrmann, J.; Matta-Camacho, E.; Shang, J.; Campbell, S.; Wilson, H.D.; Granados, J.; et al. Identification of a Binding Site for Unsaturated Fatty Acids in the Orphan Nuclear Receptor Nurr1. ACS Chem. Biol. 2016, 11, 1795-1799. [CrossRef] [PubMed]

75. Maira, M.; Martens, C.; Philips, A.; Drouin, J. Heterodimerization between members of the Nur subfamily of orphan nuclear receptors as a novel mechanism for gene activation. Mol. Cell. Biol. 1999, 19, 7549-7557. [CrossRef] [PubMed]

76. Giguère, V. Orphan nuclear receptors: From gene to function. Endocr. Rev. 1999, 20, 689-725. [CrossRef]

77. Kim, K.-S.; Kim, C.-H.; Hwang, D.-Y.; Seo, H.; Chung, S.; Hong, S.J.; Lim, J.-K.; Anderson, T.; Isacson, O. Orphan nuclear receptor Nurr1 directly transactivates the promoter activity of the tyrosine hydroxylase gene in a cell-specific manner. J. Neurochem. 2003, 85, 622-634. [CrossRef]

78. Wallén A, A.; Castro, D.S.; Zetterström, R.H.; Karlén, M.; Olson, L.; Ericson, J.; Perlmann, T. Orphan nuclear receptor Nurr1 is essential for Ret expression in midbrain dopamine neurons and in the brain stem. Mol. Cell. Neurosci. 2001, 18, 649-663. [CrossRef]

79. Smith, K.M.; Bauer, L.; Fischer, M.; Barkley, R.; Navia, B.A. Identification and characterization of human NR4A2 polymorphisms in attention deficit hyperactivity disorder. Am. J. Med. Genet. Part B 2005, 133B, 57-63. [CrossRef]

80. Buervenich, S.; Carmine, A.; Arvidsson, M.; Xiang, F.; Zhang, Z.; Sydow, O.; Jönsson, E.G.; Sedvall, G.C.; Leonard, S.; Ross, R.G.; et al. NURR1 mutations in cases of schizophrenia and manic-depressive disorder. Am. J. Med. Genet. 2000, 96, 808-813. [CrossRef]

81. Reuter, M.S.; Krumbiegel, M.; Schlüter, G.; Ekici, A.B.; Reis, A.; Zweier, C. Haploinsufficiency of NR4A2 is associated with a neurodevelopmental phenotype with prominent language impairment. Am. J. Med. Genet. Part A 2017, 173, 2231-2234. [CrossRef]

82. Campos-Melo, D.; Galleguillos, D.; Sánchez, N.; Gysling, K.; Andrés, M.E. Nur transcription factors in stress and addiction. Front. Mol. Neurosci. 2013, 6, 44. [CrossRef] [PubMed]

83. Fedeli, D.; Montani, M.; Carloni, M.; Nasuti, C.; Amici, A.; Gabbianelli, R. Leukocyte Nurr1 as peripheral biomarker of early-life environmental exposure to permethrin insecticide. Biomarkers 2012, 17, 604-609. [CrossRef] [PubMed]

84. Martens, C.; Bilodeau, S.; Maira, M.; Gauthier, Y.; Drouin, J. Protein-protein interactions and transcriptional antagonism between the subfamily of NGFI-B/Nur77 orphan nuclear receptors and glucocorticoid receptor. Mol. Endocrinol. 2005, 19, 885-897. [CrossRef] [PubMed]

85. Rojas, P.; Joodmardi, E.; Perlmann, T.; Ogren, S.O. Rapid increase of Nurr1 mRNA expression in limbic and cortical brain structures related to coping with depression-like behavior in mice. J. Neurosci. Res. 2010, 88, 2284-2293. [CrossRef]

86. Bensinger, S.J.; Tontonoz, P. A Nurr1 Pathway for Neuroprotection. Cell 2009, 137, 26-28. [CrossRef]

87. Carpentier, R.; Sacchetti, P.; Ségard, P.; Staels, B.; Lefebvre, P. The glucocorticoid receptor is a co-regulator of the orphan nuclear receptor Nurr1. J. Neurochem. 2008, 104, 777-789. [CrossRef]

88. Luo, Y. The function and mechanisms of Nurr1 action in midbrain dopaminergic neurons, from development and maintenance to survival. Int. Rev. Neurobiol. 2012, 102, 1-22.

89. Fan, X.; Luo, G.; Ming, M.; Pu, P.; Li, L.; Yang, D.; Le, W. Nurr1 expression and its modulation in microglia. Neuroimmunomodulation 2009, 16, 162-170. [CrossRef]

90. Kurakula, K.; Koenis, D.S.; van Tiel, C.M.; de Vries, C.J.M. NR4A nuclear receptors are orphans but not lonesome. Biochim. Biophys. Acta 2014, 1843, 2543-2555. [CrossRef]

91. Wan, P.K.; Siu, M.K.; Leung, T.H.; Mo, X.-T.; Chan, K.K.; Ngan, H.Y. Role of Nurr1 in Carcinogenesis and Tumor Immunology: A State of the Art Review. Cancers 2020, 12, 3044. [CrossRef] 
92. Veum, V.L.; Dankel, S.N.; Gjerde, J.; Nielsen, H.J.; Solsvik, M.H.; Haugen, C.; Christensen, B.J.; Hoang, T.; Fadnes, D.J.; Busch, C.; et al. The nuclear receptors NUR77, NURR1 and NOR1 in obesity and during fat loss. Int. J. Obes. (Lond.) 2012, 36, 1195-1202. [CrossRef] [PubMed]

93. Xu, Y.; Huang, Q.; Zhang, W.; Wang, Y.; Zeng, Q.; He, C.; Xue, J.; Chen, J.; Hu, X.; Xu, Y. Decreased expression levels of Nurr1 are associated with chronic inflammation in patients with type 2 diabetes. Mol. Med. Rep. 2015, 12, 5487-5493. [CrossRef] [PubMed]

94. Ranhotra, H.S. The NR4A orphan nuclear receptors: Mediators in metabolism and diseases. J. Recept. Signal Transduct. 2015, 35, 184-188. [CrossRef]

95. Bonta, P.I.; van Tiel, C.M.; Mariska, V.; Pols, T.W.H.; van Thienen, J.V.; Valérie, F.; Karin, A.E.; Jurgen, S.; Arnold, S.C.; van der Poll, T.; et al. Nuclear Receptors Nur77, Nurr1, and NOR-1 Expressed in Atherosclerotic Lesion Macrophages Reduce Lipid Loading and Inflammatory Responses. Arterioscler. Thromb. Vasc. Biol. 2006, 26, 2288-2294. [CrossRef] [PubMed]

96. McMorrow, J.P.; Murphy, E.P. Inflammation: A role for NR4A orphan nuclear receptors? Biochem. Soc. Trans. 2011, 39, 688-693. [CrossRef] [PubMed]

97. Oh, M.; Kim, S.Y.; Gil, J.-E.; Byun, J.-S.; Cha, D.-W.; Ku, B.; Lee, W.; Kim, W.-K.; Oh, K.-J.; Lee, E.-W.; et al. Nurr1 performs its anti-inflammatory function by regulating RasGRP1 expression in neuro-inflammation. Sci. Rep. 2020, 10, 10755. [CrossRef] [PubMed]

98. Willems, S.; Kilu, W.; Ni, X.; Chaikuad, A.; Knapp, S.; Heering, J.; Merk, D. The orphan nuclear receptor Nurr1 is responsive to non-steroidal anti-inflammatory drugs. Commun. Chem. 2020, 3, 85. [CrossRef]

99. Fedeli, D.; Montani, M.; Bordoni, L.; Galeazzi, R.; Nasuti, C.; Correia-Sá, L.; Domingues, V.F.; Jayant, M.; Brahmachari, V.; Massaccesi, L.; et al. In vivo and in silico studies to identify mechanisms associated with Nurr1 modulation following early life exposure to permethrin in rats. Neuroscience 2017, 340, 411-423. [CrossRef]

100. Bordoni, L.; Fedeli, D.; Nasuti, C.; Capitani, M.; Fiorini, D.; Gabbianelli, R. Permethrin pesticide induces NURR1 up-regulation in dopaminergic cell line: Is the pro-oxidant effect involved in toxicant-neuronal damage? Comp. Biochem. Physiol. C Toxicol. Pharmacol. 2017, 201, 51-57. [CrossRef]

101. Carloni, M.; Nasuti, C.; Fedeli, D.; Montani, M.; Vadhana, M.S.D.; Amici, A.; Gabbianelli, R. Early life permethrin exposure induces long-term brain changes in Nurr1, NF-kB and Nrf-2. Brain Res. 2013, 1515, 19-28. [CrossRef]

102. Aye, I.L.M.H.; Lager, S.; Ramirez, V.I.; Gaccioli, F.; Dudley, D.J.; Jansson, T.; Powell, T.L. Increasing maternal body mass index is associated with systemic inflammation in the mother and the activation of distinct placental inflammatory pathways. Biol. Reprod. 2014, 90, 129. [CrossRef] [PubMed]

103. Challier, J.C.; Basu, S.; Bintein, T.; Minium, J.; Hotmire, K.; Catalano, P.M.; Hauguel-de Mouzon, S. Obesity in pregnancy stimulates macrophage accumulation and inflammation in the placenta. Placenta 2008, 29, 274-281. [CrossRef] [PubMed]

104. Kirwan, J.P.; Hauguel-De Mouzon, S.; Lepercq, J.; Challier, J.-C.; Huston-Presley, L.; Friedman, J.E.; Kalhan, S.C.; Catalano, P.M. TNF-alpha is a predictor of insulin resistance in human pregnancy. Diabetes 2002, 51, 2207-2213. [CrossRef] [PubMed]

105. Lappas, M. The NR4A receptors Nurr1 and Nur77 are increased in human placenta from women with gestational diabetes. Placenta 2014, 35, 866-875. [CrossRef]

106. Radaelli, T.; Varastehpour, A.; Catalano, P.; Hauguel-de Mouzon, S. Gestational diabetes induces placental genes for chronic stress and inflammatory pathways. Diabetes 2003, 52, 2951-2958. [CrossRef] [PubMed]

107. Anisman, H.; Merali, Z. Cytokines, stress, and depressive illness. Brain. Behav. Immun. 2002, 16, 513-524. [CrossRef]

108. Irwin, M.R.; Miller, A.H. Depressive disorders and immunity: 20 years of progress and discovery. Brain. Behav. Immun. 2007, 21, 374-383. [CrossRef]

109. Goldsmith, D.R.; Rapaport, M.H.; Miller, B.J. A meta-analysis of blood cytokine network alterations in psychiatric patients: Comparisons between schizophrenia, bipolar disorder and depression. Mol. Psychiatry 2016, 21, 1696-1709. [CrossRef]

110. Irwin, M.R.; Cole, S.W. Reciprocal regulation of the neural and innate immune systems. Nat. Rev. Immunol. 2011, 11, 625-632. [CrossRef]

111. Himmerich, H.; Patsalos, O.; Lichtblau, N.; Ibrahim, M.A.A.; Dalton, B. Cytokine Research in Depression: Principles, Challenges, and Open Questions. Front. Psychiatry 2019, 10, 30. [CrossRef] 
112. Himmerich, H.; Minkwitz, J.; Kirkby, K.C. Weight Gain and Metabolic Changes During Treatment with Antipsychotics and Antidepressants. Endocr. Metab. Immune Disord. Drug Targets 2015, 15, 252-260. [CrossRef] [PubMed]

113. Pearen, M.A.; Muscat, G.E.O. Minireview: Nuclear hormone receptor 4A signaling: Implications for metabolic disease. Mol. Endocrinol. 2010, 24, 1891-1903. [CrossRef] [PubMed]

114. Holdsworth-Carson, S.J.; Permezel, M.; Riley, C.; Rice, G.E.; Lappas, M. Peroxisome proliferator-activated receptors and retinoid $\mathrm{X}$ receptor-alpha in term human gestational tissues: Tissue specific and labour-associated changes. Placenta 2009, 30, 176-186. [CrossRef] [PubMed]

115. Holdsworth-Carson, S.J.; Lim, R.; Mitton, A.; Whitehead, C.; Rice, G.E.; Permezel, M.; Lappas, M. Peroxisome proliferator-activated receptors are altered in pathologies of the human placenta: Gestational diabetes mellitus, intrauterine growth restriction and preeclampsia. Placenta 2010, 31, 222-229. [CrossRef] [PubMed]

116. Holdsworth-Carson, S.J.; Permezel, M.; Rice, G.E.; Lappas, M. Preterm and infection-driven preterm labor: The role of peroxisome proliferator-activated receptors and retinoid X receptor. Reproduction 2009, 137, 1007-1015. [CrossRef]

117. Christiaens, I.; Zaragoza, D.B.; Guilbert, L.; Robertson, S.A.; Mitchell, B.F.; Olson, D.M. Inflammatory processes in preterm and term parturition. J. Reprod. Immunol. 2008, 79, 50-57. [CrossRef]

118. Lappas, M. Effect of spontaneous term labour on the expression of the NR4A receptors nuclear receptor related 1 protein (Nurr1), neuron-derived clone 77 (Nur77) and neuron-derived orphan receptor 1 (NOR1) in human fetal membranes and myometrium. Reprod. Fertil. Dev. 2016, 28, 893-906. [CrossRef]

119. Romero, R.; Espinoza, J.; Kusanovic, J.P.; Gotsch, F.; Hassan, S.; Erez, O.; Chaiworapongsa, T.; Mazor, M. The preterm parturition syndrome. BJOG 2006, 113 (Suppl. 3), 17-42. [CrossRef]

120. Weinstock, M. Alterations induced by gestational stress in brain morphology and behaviour of the offspring. Prog. Neurobiol. 2001, 65, 427-451. [CrossRef]

121. Weinstock, M. Can the behaviour abnormalities induced by gestational stress in rats be prevented or reversed? Stress 2002, 5, 167-176. [CrossRef]

122. Huizink, A.C.; Mulder, E.J.H.; Buitelaar, J.K. Prenatal stress and risk for psychopathology: Specific effects or induction of general susceptibility? Psychol. Bull. 2004, 130, 115-142. [CrossRef] [PubMed]

123. Saucedo-Cardenas, O.; Quintana-Hau, J.D.; Le, W.D.; Smidt, M.P.; Cox, J.J.; De Mayo, F.; Burbach, J.P.; Conneely, O.M. Nurr1 is essential for the induction of the dopaminergic phenotype and the survival of ventral mesencephalic late dopaminergic precursor neurons. Proc. Natl. Acad. Sci. USA 1998, 95, 4013-4018. [CrossRef] [PubMed]

124. Katunar, M.R.; Saez, T.; Brusco, A.; Antonelli, M.C. Immunocytochemical expression of dopamine-related transcription factors Pitx3 and Nurr1 in prenatally stressed adult rats. J. Neurosci. Res. 2009, 87, 1014-1022. [CrossRef] [PubMed]

125. Montes, P.; Ruiz-Sánchez, E.; Calvillo, M.; Rojas, P. Active coping of prenatally stressed rats in the forced swimming test: Involvement of the Nurr1 gene. Stress 2016, 19, 506-515. [CrossRef] [PubMed]

126. Sun, Y.; Li, Y.-S.; Yang, J.-W.; Yu, J.; Wu, Y.-P.; Li, B.-X. Exposure to atrazine during gestation and lactation periods: Toxicity effects on dopaminergic neurons in offspring by downregulation of Nurr1 and VMAT2. Int. J. Mol. Sci. 2014, 15, 2811-2825. [CrossRef]

127. Patel, V.P.; Chu, C.T. Nuclear transport, oxidative stress, and neurodegeneration. Int. J. Clin. Exp. Pathol. 2011, 4, 215-229.

128. Bordoni, L.; Nasuti, C.; Mirto, M.; Caradonna, F.; Gabbianelli, R. Intergenerational Effect of Early Life Exposure to Permethrin: Changes in Global DNA Methylation and in Nurr1 Gene Expression. Toxics 2015, 3, 451-461. [CrossRef]

129. Romoli, B.; Lozada, A.F.; Sandoval, I.M.; Manfredsson, F.P.; Hnasko, T.S.; Berg, D.K.; Dulcis, D. Neonatal Nicotine Exposure Primes Midbrain Neurons to a Dopaminergic Phenotype and Increases Adult Drug Consumption. Biol. Psychiatry 2019, 86, 344-355. [CrossRef]

130. Brown, A.S.; Derkits, E.J. Prenatal infection and schizophrenia: A review of epidemiologic and translational studies. Am. J. Psychiatry 2010, 167, 261-280. [CrossRef]

131. Brown, A.S.; Meyer, U. Maternal Immune Activation and Neuropsychiatric Illness: A Translational Research Perspective. Am. J. Psychiatry 2018, 175, 1073-1083. [CrossRef] 
132. Vuillermot, S.; Joodmardi, E.; Perlmann, T.; Ögren, S.O.; Feldon, J.; Meyer, U. Prenatal immune activation interacts with genetic Nurr1 deficiency in the development of attentional impairments. J. Neurosci. 2012, 32, 436-451. [CrossRef] [PubMed]

133. Shao, C.-Z.; Xia, K.-P. Sevoflurane anesthesia represses neurogenesis of hippocampus neural stem cells via regulating microRNA-183-mediated NR4A2 in newborn rats. J. Cell. Physiol. 2019, 234, 3864-3873. [CrossRef] [PubMed]

134. Lallier, S.W.; Graf, A.E.; Waidyarante, G.R.; Rogers, L.K. Nurr1 expression is modified by inflammation in microglia. Neuroreport 2016, 27, 1120-1127. [CrossRef] [PubMed]

135. Popichak, K.A.; Hammond, S.L.; Moreno, J.A.; Afzali, M.F.; Backos, D.S.; Slayden, R.D.; Safe, S.; Tjalkens, R.B. Compensatory Expression of Nur77 and Nurr1 Regulates NF-кB-Dependent Inflammatory Signaling in Astrocytes. Mol. Pharmacol. 2018, 94, 1174-1186. [CrossRef]

136. Lungu, G.; Stoica, G.; Ambrus, A. MicroRNA profiling and the role of microRNA-132 in neurodegeneration using a rat model. Neurosci. Lett. 2013, 553, 153-158. [CrossRef] [PubMed]

137. Yang, Z.; Li, T.; Li, S.; Wei, M.; Qi, H.; Shen, B.; Chang, R.C.-C.; Le, W.; Piao, F. Altered Expression Levels of MicroRNA-132 and Nurr1 in Peripheral Blood of Parkinson's Disease: Potential Disease Biomarkers. ACS Chem. Neurosci. 2019, 10, 2243-2249. [CrossRef]

138. Valsecchi, V.; Boido, M.; Montarolo, F.; Guglielmotto, M.; Perga, S.; Martire, S.; Cutrupi, S.; Iannello, A.; Gionchiglia, N.; Signorino, E.; et al. The transcription factor Nurr1 is upregulated in amyotrophic lateral sclerosis patients and SOD1-G93A mice. Dis. Model. Mech. 2020, 13. [CrossRef]

139. Jakaria, M.; Haque, M.E.; Cho, D.-Y.; Azam, S.; Kim, I.-S.; Choi, D.-K. Molecular Insights into NR4A2(Nurr1): An Emerging Target for Neuroprotective Therapy Against Neuroinflammation and Neuronal Cell Death. Mol. Neurobiol. 2019, 56, 5799-5814. [CrossRef]

140. Moon, H.; Jeon, S.G.; Kim, J.-I.; Kim, H.S.; Lee, S.; Kim, D.; Park, S.; Moon, M.; Chung, H. Pharmacological Stimulation of Nurr1 Promotes Cell Cycle Progression in Adult Hippocampal Neural Stem Cells. Int. J. Mol. Sci. 2019, 21, 4. [CrossRef]

141. Munoz-Tello, P.; Lin, H.; Khan, P.; de Vera, I.M.S.; Kamenecka, T.M.; Kojetin, D.J. Assessment of NR4A Ligands that Directly Bind and Modulate the Orphan Nuclear Receptor Nurr1. bioRxiv 2020. [CrossRef]

142. de Vera, I.M.S.; Munoz-Tello, P.; Zheng, J.; Dharmarajan, V.; Marciano, D.P.; Matta-Camacho, E.; Giri, P.K.; Shang, J.; Hughes, T.S.; Rance, M.; et al. Defining a Canonical Ligand-Binding Pocket in the Orphan Nuclear Receptor Nurr1. Structure 2019, 27, 66-77.e5. [CrossRef] [PubMed]

143. Bruning, J.M.; Wang, Y.; Oltrabella, F.; Tian, B.; Kholodar, S.A.; Liu, H.; Bhattacharya, P.; Guo, S.; Holton, J.M.; Fletterick, R.J.; et al. Covalent Modification and Regulation of the Nuclear Receptor Nurr1 by a Dopamine Metabolite. Cell Chem. Biol. 2019, 26, 674-685.e6. [CrossRef] [PubMed]

144. Bordoni, L.; Gabbianelli, R. Primers on nutrigenetics and nutri(epi)genomics: Origins and development of precision nutrition. Biochimie 2019, 160, 156-171. [CrossRef] [PubMed]

Publisher's Note: MDPI stays neutral with regard to jurisdictional claims in published maps and institutional affiliations.

(C) 2020 by the authors. Licensee MDPI, Basel, Switzerland. This article is an open access article distributed under the terms and conditions of the Creative Commons Attribution (CC BY) license (http://creativecommons.org/licenses/by/4.0/). 